\title{
Universal immunity to influenza must outwit immune evasion
}

\author{
Sergio Quiñones-Parra ${ }^{1}$, Liyen Loh ${ }^{1}$, Lorena E. Brown ${ }^{1}$, Katherine Kedzierska ${ }^{1}{ }^{\dagger}{ }^{2}$ and \\ Sophie A. Valkenburg ${ }^{2 * t}$
}

${ }^{1}$ Department of Microbiology and Immunology, The University of Melbourne at the Peter Doherty Institute for Infection and Immunity, Parkville, VIC, Australia

${ }^{2}$ Centre for Influenza Research and School of Public Health, The University of Hong Kong, Hong Kong, China

\section{Edited by:}

Magdalena Plebanski, Monash

University, Australia

Reviewed by:

Birgit Strobl, University of Veterinary

Medicine Vienna, Austria

Shuo Li, Burnet Institute, Australia

\section{*Correspondence:}

Katherine Kedzierska, Department

of Microbiology and Immunology,

The University of Melbourne,

Parkville, Melbourne, VIC 3010 ,

Australia

e-mail:kkedz@unimelb.edu.au:

Sophie A. Valkenburg, Center of

Influenza Research and School of

Public Health, The University of

Hong Kong, L5-25 Laboratory Block,

21 Sassoon rd., Pokfulam, Hong

Kong, China

e-mail: sophiev@hku.hk

${ }^{\dagger}$ These authors have contributed equally to this work.
Although an influenza vaccine has been available for 70 years, influenza virus still causes seasonal epidemics and worldwide pandemics. Currently available vaccines elicit strain-specific antibody (Ab) responses to the surface haemagglutinin ( $H A)$ and neuraminidase (NA) proteins, but these can be ineffective against serologically-distinct viral variants and novel subtypes. Thus, there is a great need for cross-protective or "universal" influenza vaccines to overcome the necessity for annual immunization against seasonal influenza and to provide immunity to reduce the severity of infection with pandemic or outbreak viruses. It is well established that natural influenza infection can provide cross-reactive immunity that can reduce the impact of infection with distinct influenza type A strains and subtypes, including H1N1, H3N2, H2N2, H5N1, and H7N9. The key to generating universal influenza immunity through vaccination is to target functionally-conserved regions of the virus, which include epitopes on the internal proteins for cross-reactive T cell immunity or on the HA stem for broadly reactive Ab responses. In the wake of the 2009 H1N1 pandemic, broadly neutralizing antibodies (bnAbs) have been characterized and isolated from convalescent and vaccinated individuals, inspiring development of new vaccination techniques to elicit such responses. Induction of influenza-specific $T$ cell responses through vaccination has also been recently examined in clinical trials. Strong evidence is available from human and animal models of influenza to show that established influenza-specific $T$ cell memory can reduce viral shedding and symptom severity. However, the published evidence also shows that $\mathrm{CD} 8^{+} \mathrm{T}$ cells can efficiently select immune escape mutants early after influenza virus infection. Here, we discuss universal immunity to influenza viruses mediated by both cross-reactive $T$ cells and Abs, the mechanisms of immune evasion in influenza, and propose how to counteract commonly occurring immune-escape variants.

Keywords: influenza viruses, $\mathrm{T}$ cells memory, antibodies, viral escape mechanisms, vaccine design

\section{INTRODUCTION}

Immunization is the most cost effective public health measure to prevent the spread of infectious diseases. Influenza causes seasonal epidemics as well as periodic global pandemics due to the introduction of novel strains and sporadic outbreaks from animal reservoirs. During the 2009 H1N1 pandemic, the overall infection rate was $10 \%$, although the infection rate rose to $43 \%$ in schoolaged children (Wu et al., 2010). Yet, an influenza vaccine has been available since the 1940's.

Current influenza vaccines predominantly mediate protection by eliciting neutralizing $\mathrm{Ab}$ responses to epitopes on the head region of the virion surface glycoprotein, $\mathrm{HA}$, and also to the NA. The traditional trivalent influenza vaccine (TIV) is based on either inactivated whole/subvirion virus or detergent-disrupted virions, and is administered as an intramuscular injection to elicit systemic Ab responses. Alternatively, the live attenuated influenza vaccine (LAIV), is given intranasally. The LAIV vaccine does not boost $\mathrm{T}$ cell immunity in adults (He et al., 2006), but does improve protection by eliciting Ab responses locally in the respiratory tract. Notably, LAIV in children is able to establish influenza-specific $\mathrm{T}$ cell responses, possibly due to their naïve infection status (He et al., 2006). Whilst LAIV has increased protection compared to TIV (Monto et al., 2009), TIV has much wider use due to a greater number of manufacturers and constrained use of LAIV in the elderly and very young.

Originally, the influenza vaccine was a monovalent preparation, based on the common circulating strain of influenza A virus (IAV) and was swiftly updated to include an influenza B virus when these were recognized in the 1940's. Since the 1970's, a trivalent vaccine has been used to provide coverage for $\mathrm{H} 1 \mathrm{~N} 1$, $\mathrm{H} 3 \mathrm{~N} 2$, and influenza B virus, which now co-circulate. Even more recently, in 2013, the vaccine has become available in a quadrivalent form incorporating both Victoria and Yamagata lineages of influenza B. Thus, the number of vaccine strains has progressively been increased from a single strain to four, to provide broader protection and overcome the diversity of multiple influenza virus 
subtypes and lineages. Nevertheless, within each subtype or lineage, constant antigenic drift gives rise to new and unpredictable antigenic variants that are not necessarily represented in the vaccine. Mismatch between the vaccine strain, predicted on the basis of antigenically novel isolates circulating in the previous winter in the opposite hemisphere, and the actual strain that emerges in the current winter can result in significant loss of vaccine effectiveness.

The mechanism of action of current vaccines, which mediate protection by induction of neutralizing $\mathrm{Ab}$ responses to the rapidly changing head of the HA protein, renders it ineffective after a few years at best, once all the antigenic regions on the head of the HA have mutated in response to pre-existing Ab. Inactivated vaccines are also very poor inducers of $\mathrm{CD}^{+} \mathrm{T}$ cell responses, presumably because of inefficient uptake and priming by appropriate antigen presenting cells (APCs). There is evidence from animal models that TIV vaccination can actually inhibit the induction of cross-reactive $\mathrm{T}$ cell responses (Bodewes et al., 2011), which require active virus replication, resulting in a greater susceptibility to subsequent infection by novel viruses such as H5N1 (Bodewes et al., 2010). With an increased appreciation of the immune response and its induction, it is time to consider new vaccine approaches for seasonal influenza that additionally or exclusively target functionally conserved regions of the influenza virus, and may therefore provide some level of disease reduction against serologically distinct emergent strains, even in a pandemic context.

IAVs, whose ancestral host is aquatic birds, have spread to many other species including domestic poultry, horses, swine, humans, and even fruit bats. Although there are 17 different distinct HA subtypes and 10 NA subtypes thus far identified for IAVs, only $\mathrm{H} 1 \mathrm{~N} 1$ and $\mathrm{H} 3 \mathrm{~N} 2$, and previously $\mathrm{H} 2 \mathrm{~N} 2$, subtypes have become endemic in humans causing continual human transmission and seasonal epidemics. The introduction of other novel subtypes, as exemplified by the H5N1, H7N9, and H10N8 strains, cause sporadic human infections and are not yet fully adapted for efficient human-to-human transmission. The segmented nature of the influenza virus genome facilitates reassortment to generate novel hybrid viruses between influenza viruses from different species, some of pandemic potential. Furthermore, the error-prone viral RNA-dependent RNA polymerase, which enables the generation of viral mutants, facilitates selection of influenza viruses resistant to anti-viral drugs and immune effectors. Thus, influenza is continually evolving and novel influenza viruses from animal reservoirs can cause unpredictable outbreaks, such as the most recent outbreaks from swine in the US (variant H3N2), poultry markets of China (H7N9) and Hong Kong (H5N1), leaving us unprepared and unprotected. Furthermore, H7N9 and H5N1 infections are highly lethal, with around 30 and $60 \%$ hospitalization-associated mortality, respectively. Therefore, there is a dire need for a vaccine that is effective against a "moving target," influenza viruses.

\section{CROSS-REACTIVE ANTIBODIES LEAD TO RENEWED INTEREST IN B CELL VACCINES}

The novel 2009 H1N1 pandemic virus (pH1N1-09) spread worldwide within 4 months due to minimal specific $\mathrm{Ab}$ immunity across the population. However, due to the novelty of the HA protein in some cases infection or vaccination resulted in the induction of novel broadly "neutralizing" antibody responses (reviewed in Corti and Lanzavecchia, 2013), leading to a renewed interest in developing the targets of theses Abs (summarized in Table 1) for universal vaccines.

The HA glycoprotein on the influenza virion exists as a trimer and dominates the surface of the virus. The amino acid sequence shows $40-70 \%$ conservation between different HA subtypes (e.g. $\mathrm{H} 1$ vs. H7) and greater than $80 \%$ between strains within a single subtype (e.g. H1 strains). Subtype variation underlies the classification of influenza viruses into two phylogenetic groups: group $1(\mathrm{H} 5, \mathrm{H} 2, \mathrm{H} 1)$ and $2(\mathrm{H} 3, \mathrm{H} 7, \mathrm{H} 10)$. Each HA monomer consists of two disulphide-linked polypeptide chains HAl and HA2 (Figures 1A,B). The majority of the HA1 chain goes to make up the globular head of the molecule, which contains the receptor-binding domain $(\mathrm{RBD})$. The $\mathrm{RBD}$ is the primary target for $\mathrm{nAb}$ responses elicited by current vaccines, and therefore random mutations that lead to single amino acid changes in $\mathrm{Ab}$ binding sites in this domain are selected under pressure to avoid further such Abs, resulting in the process of antigenic drift. In some instances, amino acid changes that alter the glycosylation pattern in the head region can also influence $\mathrm{Ab}$ binding. Some bnAbs have been isolated that recognize epitopes on the HA head region, e.g. FE17 (Corti et al., 2010), S139/1 (Yoshida

Table 1 | Potential targets for a universal influenza vaccine and their limitations.

\begin{tabular}{|c|c|c|c|c|c|c|}
\hline Protein & Location & Site targetted & $\begin{array}{l}\text { Function of } \\
\text { target }\end{array}$ & Immune effector & Possible role in influenza protection & $\begin{array}{l}\text { Escape } \\
\text { possible }\end{array}$ \\
\hline \multirow[t]{2}{*}{$\mathrm{HA}$} & Virion surface & $\mathrm{HAl}_{-}$(head) & Virus binding & $\mathrm{nAb}$ & Block HA binding & Yes \\
\hline & Virion and cell surface & HA2 (stem) & Viral fusion & Non-nAb & Block HA maturation, Fc-mediated lysis & No \\
\hline NA & Virion surface & Sialidase & Virus release & Non-nAb & Block NA cleavage and virus release & Yes \\
\hline M2 & Infected cell surface & $\begin{array}{l}\mathrm{M} 2 \\
\text { Ectodomain }\end{array}$ & Ion channel & Non-nAb & Block virus entry & No \\
\hline \multirow[t]{2}{*}{ NP } & Infected cell surface & Unknown & RNP structure & Non-nAb & ADCC and complement mediated lysis & Unknown \\
\hline & Infected cell & $\begin{array}{l}\text { Conserved } \\
\text { pMHC }\end{array}$ & RNP structure & T cells (CD4+ and CD8+) & T cell cytotoxicity reduces viral load & Yes (limited) \\
\hline All & Infected cell & $\begin{array}{l}\text { Conserved } \\
\text { pMHC }\end{array}$ & Various & T cells (CD4+ and CD8+) & T cell cytotoxicity reduces viral load & Yes (limited) \\
\hline
\end{tabular}




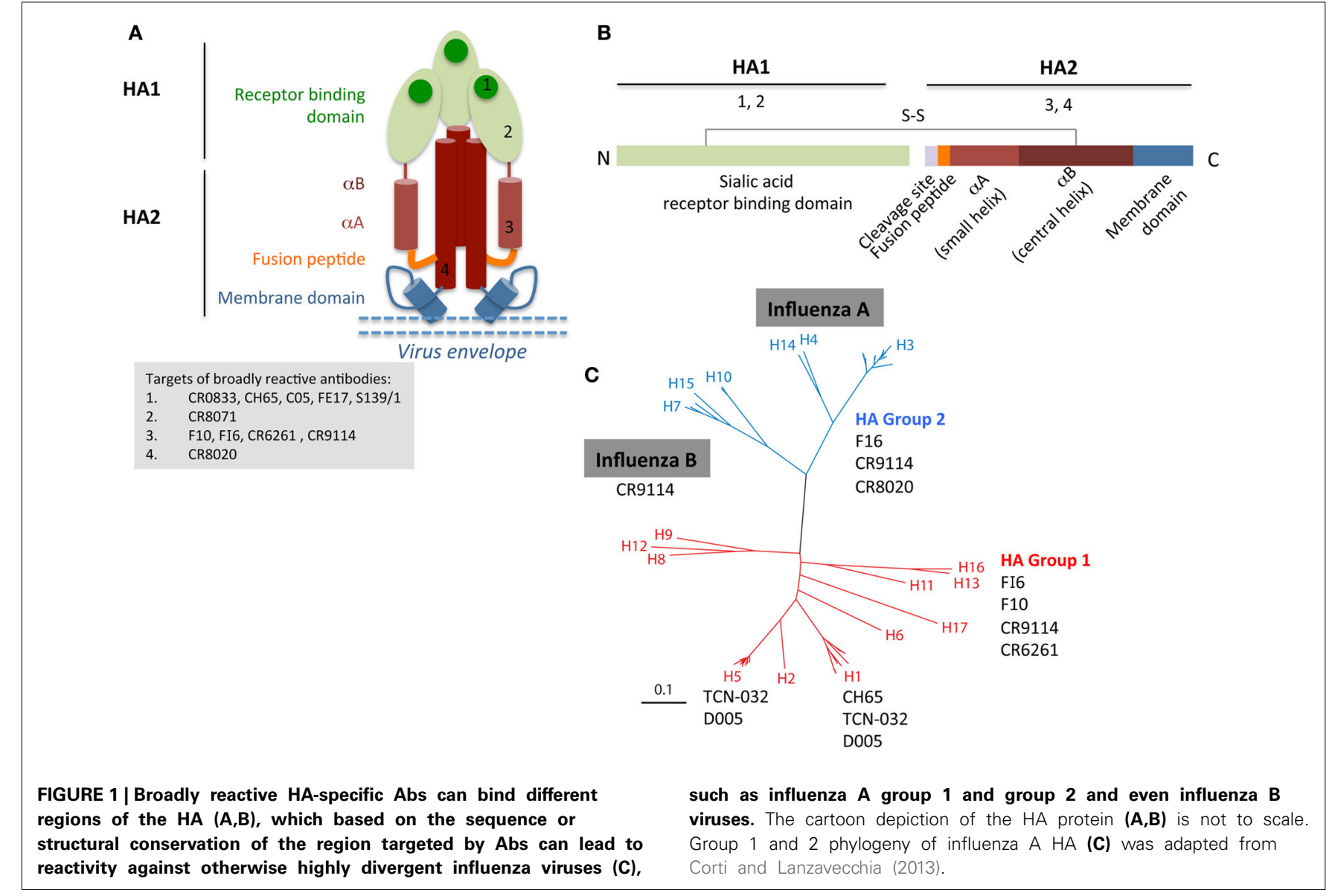

B

et al., 2009), CH65 (Whittle et al., 2011), C05 (Ekiert et al., 2012) (Figure 1). However, escape mutations in the HA1 can be generated either at $\mathrm{Ab}$ binding sites or flanking residues after several passages in vitro, thus limiting the use of head-specific bnAbs.

The stem of the HA, which supports the globular head, contains a hydrophobic fusion region which is situated at the $\mathrm{N}$-terminus of the HA2 chain. This region plays a crucial role during viral entry into cells, allowing endosome escape of the viral genome, and is functionally and structurally conserved across HA subtypes and therefore not susceptible to drift. The stem contains a number of epitopes spanning the fusion region, which are conserved across different influenza subtypes (Okuno et al., 1993), enabling the isolation of influenza-specific broadly cross-reactive Abs capable of recognizing either group $1 \mathrm{HA}$ (from Crucell CR6261) (Ekiert et al., 2009), group 2 HA (CR8020) (Ekiert et al., 2011), both group 1 and 2 HAs (FI6) (Corti et al., 2011), or even recognize different influenza A and B strains (CR9114) (Dreyfus et al., 2012) (reviewed in Corti and Lanzavecchia, 2013) (Figure 1). One hypothesis for the induction of post-pandemic group 1-specific stem Abs is that the $\mathrm{pH} 1 \mathrm{N1}-09$ virus displayed a sufficiently distinct HA1 head domain when compared to the pre-pandemic $\mathrm{H} 1 \mathrm{~N} 1$ viruses, that pre-existing memory B cells specific for the HA head could not be recruited stem-specific responses. Thus, H1N1-2009 virus exposure generated a primary
HA1-specific $\mathrm{H} 1 \mathrm{Ab}$ response but in addition was able to boost the low frequency group 1 stem specific Abs (Corti et al., 2010; Margine et al., 2013).

Importantly, HA2 stem-specific Abs prevent the conformational changes required for viral entry and membrane fusion, thus mutational escape is not possible due to the critical function and conserved helical structure of the stem. However, very high concentrations of stem-specific Abs are often required to mediate virus neutralizing activity, as they are 100-1000 times less potent than HA head-specific Abs (Corti et al., 2010). Typically, stemspecific Abs do not inhibit sialic acid binding by the receptorbinding site, as do classical head-specific Abs. For this reason they are unable to be identified by standard haemaglutination inhibition (HAI) assays, and are measured by virus neutralization or modified ELISA type assays. It should also be noted that bnAbs often represent highly edited $B$ cell receptor sequences from germline requiring affinity maturation and co-ordination with $\mathrm{T}$ follicular helper cells (reviewed in Corti and Lanzavecchia, 2013), and thus they are often very rare and of low frequency. Advanced B cell cloning techniques have enabled the identification and isolation of unique bnAbs (Corti et al., 2011) for prophylactic and therapeutic use.

Vaccination with the conserved HA2 stem was first explored as an Abs target nearly 30 years ago (Graves et al., 1983), and is now receiving renewed attention in the wake of the 2009 
pandemic. Various methods have been employed by different research groups to elicit bnAbs following exposure to influenza, such as headless HA protein or virus exposing the stem (Steel et al., 2010; Wang et al., 2010), prime-boost with a chimeric HA (Krammer et al., 2013) or by sequential infection with different influenza subtypes (Krammer et al., 2012) and DNA-prime heterologous-boost vaccination (Wei et al., 2010). Furthermore, bnAbs (CR6261, CH65, and scF10) have even been incorporated directly into self-assembling nanoparticles, providing long-term passive immunity in animal models (Kanekiyo et al., 2013), a strategy that could potentially be beneficial for the elderly or immunocompromised. Importantly, using the murine model it has been recently elucidated that the protective effect of some broadly-neutralizing stem-specific Abs is dependent on Fc $\gamma \mathrm{R}$ interactions (DiLillo et al., 2014) so that their main activity is not by classical neutralization of virus particles.

Other broadly reactive Abs that work in this way are those directed to the highly conserved surface M2 ion channel ectodomain (M2e). M2 is only expressed in very small amounts on the virion surface but is present on the infected cell surface where it can form a target for cross-reactive lytic responses. M2especific Abs are induced only at very low frequency by influenza infection, and are not elicited at all by the standard TIV vaccination, although they can be induced by M2e-specific vaccines (Neirynck et al., 1999; Mozdzanowska et al., 2003). Unexpectedly, Abs specific for the viral nucleoprotein (NP), which surrounds the genome, have also shown passive protection in mouse models at very high doses (Carragher et al., 2008; Lamere et al., 2011) and can be found in human serum (Sukeno et al., 1979). In vitro studies demonstrated that influenza-infected cells express low levels of NP on their surface (Virelizier et al., 1977; Yewdell et al., 1981), which may enable NP recognition by immune effectors, or alternatively, it is possible that NP-specific Abs are internalized and interrupt virus replication. Utilization of non-neutralizing NP and M2e Abs might be beneficial when combined with additional protective immune mechanisms.

Abs that are not virus neutralizing may also function in Ab-dependent cellular cytotoxicity (ADCC). pH1N1-09, H5N1specifc and NP-specific ADCC Abs have been found in the absence of $\mathrm{nAb}$ responses in healthy individuals (Jegaskanda et al., 2013b). Influenza infection, but not standard TIV vaccination of macaques, elicited H1N1-specific ADCC Ab responses (Jegaskanda et al., 2013a), thus future vaccines would need to be optimized to elicit ADCC responses.

However, a forewarning comes from recent evidence in mouse models, which showed that influenza virus was able to specifically infect influenza-specific B cell receptor (BCR)-expressing $\mathrm{B}$ cells leading to BCR editing, thus allowing establishment of viral infection despite pre-existing $\mathrm{Ab}$ responses (Dougan et al., 2013). There is also evidence from a swine vaccination model that stem-specific HA2 Abs can enhance viral fusion and increase immunopathology upon H1N1pdm infection (Khurana et al., 2013). Therefore, while broadly cross reactive Abs are an increasingly promising area for combating influenza infections of distinct strains, their use should not be without investigation and should be used in conjunction with additional immune mechanisms.

\section{HETEROSUBTYPIC T CELL RESPONSES FOR INFLUENZA}

$\mathrm{CD}^{+} \mathrm{T}$ cells recognize virus-derived peptides in the context of class I major histocompatibility antigens (MHC-I). pMHC$\mathrm{I}$ is displayed on the surface of APCs enabling $\mathrm{CD}^{+} \mathrm{T}$ cell priming and on virus-infected cells for $\mathrm{CD} 8^{+} \mathrm{T}$ cell effector function, thus infected cells can be killed before virus progeny is released. The cytotoxic function is mediated mainly via the delivery of perforin and granzymes into the infected cell (Topham et al., 1997) as well as by cytokine release (Marshall et al., 2005). Thus, $\mathrm{CD}^{+} \mathrm{T}$ cell recognition of influenza viruses is only possible for an established infection, in contrast to sterilizing $\mathrm{nAb}$ responses. However, $\mathrm{CD} 8^{+} \mathrm{T}$ cells are critical in the elimination of influenza viruses, expediting viral clearance, and reducing pathology. Seminal work from influenza challenge of healthy human volunteers showed that increased $\mathrm{T}$ cell cytotoxicity was associated with reduced virus shedding (McMichael et al., 1983b), even in volunteers lacking nAbs against the infecting virus. Moreover, high levels of influenza-specific pre-existing memory $\mathrm{T}$ cells have been associated with milder symptoms during $\mathrm{pH} 1 \mathrm{~N} 1$ infection (Sridhar et al., 2013). There is no doubt that the current Ab-based approach should be maintained, but the incorporation of an even far-from-perfect T-cell-inducing vaccine (or vaccine component) could still save millions of lives during a pandemic, as $\mathrm{T}$ cells have the potential for much broader protection than bnAbs across diverse subtypes of influenza A.

The phenomenon of heterosubtypic immunity refers to memory $\mathrm{T}$ cells generated by one subtype that can cross-react against different IAV subtypes, despite wide differences in surface glycoproteins (Braciale, 1977; Kees and Krammer, 1984; Yewdell et al., 1985; Askonas et al., 1988; Wahl et al., 2009). T cell heterosubtypic immunity is mainly due to the majority of $\mathrm{T}$ cells recognizing immunogenic peptides derived primarily from highly conserved internal influenza proteins (Elhefnawi et al., 2011). For $\mathrm{CD}^{+} \mathrm{T}$ cells, 193 immunogenic peptides presented by 51 different Human Leukocyte Antigen Class I (HLA-I) molecules have been described to date for influenza viruses (www.iedb.org). The majority of $\mathrm{CD}^{+} \mathrm{T}$ cell antigenic peptides are derived from wellconserved internal proteins NP, M1, and PB1 (Assarsson et al., 2008; Lee et al., 2008; Wu et al., 2011; Grant et al., 2013). T cell cross-reactivity between different IAVs has been demonstrated between $\mathrm{H} 1 \mathrm{~N} 1, \mathrm{H} 3 \mathrm{~N} 2, \mathrm{H} 2 \mathrm{~N} 2, \mathrm{H} 5 \mathrm{~N} 1, \mathrm{H} 3 \mathrm{~N} 2 \mathrm{v}$, and H7N9 subtypes (Table 2) (Epstein, 2006; Kreijtz et al., 2008; Greenbaum et al., 2009; Hillaire et al., 2013; Quinones-Parra et al., 2014; Van De Sandt et al., 2014). Thus, influenza-specific T cells can provide universal protection against influenza disease and are of significant interest for the design of next generation vaccines.

The viral clearing role of heterosubtypic killer $\mathrm{CD}^{+} \mathrm{T}$ cells is well established in animal models and human studies (Table 2). In a primary infection of $\mathrm{CD}^{+} \mathrm{T}$ cell-deficient mice, influenza virus clearance is delayed and mortality is increased (Bender et al., 1992), while in the absence of $\mathrm{B}$ cells or Abs, $\mathrm{CD}^{+} \mathrm{T}$ cells can provide protection against otherwise lethal influenza (Graham and Braciale, 1997; Epstein et al., 1998). Furthermore, transfer of influenza-specific $\mathrm{CD}^{+} \mathrm{T}$ cells provides heterosubtypic protection (Yap et al., 1978; Taylor and Askonas, 1986). Secondary recall responses from pre-existing memory $\mathrm{CD}^{+} \mathrm{T}$ cells, established by either influenza virus infection or vaccination (Flynn et al., 
Table 2 | Key human studies on cell-mediated immunity against IAV.

\begin{tabular}{|c|c|c|}
\hline References & Virus(es) & Description \\
\hline McMichael et al., 1983b & H1N1 & $\begin{array}{l}\text { Lymphocyte cytotoxic activity was associated with lower virus shedding in } \\
\text { individuals challenged with } \mathrm{H} 1 \mathrm{~N} 1\end{array}$ \\
\hline Gotch et al., 1988 & $\mathrm{H} 3 \mathrm{~N} 2 \rightarrow \mathrm{H} 1 \mathrm{~N} 1$ & $\begin{array}{l}\mathrm{CD}^{+} \mathrm{T} \text { cell lines generated with } \mathrm{H} 3 \mathrm{~N} 2 \text { virus lyse target cells infected with } \\
\text { Vaccinia viruses encoding NP, M1, or PB2 proteins derived from H1N1 }\end{array}$ \\
\hline Epstein, 2006 & $\mathrm{H} 1 \mathrm{~N} 1 \rightarrow \mathrm{H} 2 \mathrm{~N} 2$ & $\begin{array}{l}\text { Adults that contracted } \mathrm{H} 1 \mathrm{~N} 1 \text { influenza prior to the emergence of } \mathrm{pH} 2 \mathrm{~N} 2-57 \text { were } \\
\text { pronouncedly less susceptible to the pandemic virus }\end{array}$ \\
\hline Kreijtz et al., 2008 & $\mathrm{H} 3 \mathrm{~N} 2 \rightarrow \mathrm{H} 5 \mathrm{~N} 1$ & $\begin{array}{l}\text { CD8 }{ }^{+} \mathrm{T} \text { cell lines established with } \mathrm{H} 3 \mathrm{~N} 2 \text { cross-react with immunogenic peptides } \\
\text { derived from } \mathrm{H} 5 \mathrm{~N} 1\end{array}$ \\
\hline Lee et al., 2008 & Seasonal (s) IAV $\rightarrow \mathrm{H} 5 \mathrm{~N} 1$ & $\begin{array}{l}\mathrm{CD}^{+} \text {and } \mathrm{CD}^{+} \mathrm{T} \text { cells from } \mathrm{H} 5 \text { seronegative donors respond to peptides } \\
\text { spanning the } \mathrm{H} 5 \mathrm{~N} 1 \text { proteome }\end{array}$ \\
\hline Assarsson et al., 2008 & $\begin{array}{l}\mathrm{H} 1 \mathrm{~N} 1, \mathrm{H} 3 \mathrm{~N} 2, \mathrm{H} 2 \mathrm{~N} 2, \mathrm{H} 5 \mathrm{~N} 1, \mathrm{H} 7 \mathrm{~N} 7, \\
\mathrm{H} 6 \mathrm{~N} 1, \mathrm{H} 7 \mathrm{~N} 7 \text {, and H9N2 }\end{array}$ & $\begin{array}{l}\mathrm{CD}^{+} \text {and } \mathrm{CD}^{+} \mathrm{T} \text { cells from healthy donors respond to substantially conserved } \\
\text { immunogenic peptides }\end{array}$ \\
\hline Tu et al., 2010 & $\mathrm{sH} 1 \mathrm{~N} 1 / \mathrm{sH} 3 \mathrm{~N} 2 \rightarrow \mathrm{pH} 1 \mathrm{~N} 1-09$ & $\begin{array}{l}\text { Purified, influenza-specific memory } \mathrm{CD}^{+}{ }^{+} \mathrm{T} \text { cells expanded with sH1N1 and } \\
\text { sH3N2 recognize target cells infected with } \mathrm{pH} 1 \mathrm{~N} 1-09\end{array}$ \\
\hline Gras et al., 2010 & $\mathrm{pH} 1 \mathrm{~N} 1-09 \rightarrow \mathrm{pH} 1 \mathrm{~N} 1-1918$ & $\begin{array}{l}\text { B7-NP } 418 \text {-specific } \mathrm{CD}^{+}{ }^{+} \mathrm{T} \text { cells elicited by } \mathrm{pH} 1 \mathrm{N1}-09 \text { infection cross react with } \\
\text { the } \mathrm{pH} 1 \mathrm{~N} 1-1918-\mathrm{NP}_{418} \text { variant }\end{array}$ \\
\hline Wilkinson et al., 2012 & H3N2 & $\begin{array}{l}\text { Pre-existing } \mathrm{CD}^{+}+\mathrm{T} \text { cell responses correlated with lower virus shedding and } \\
\text { disease severity upon challenge with } \mathrm{H} 3 \mathrm{~N} 2 \text { in seronegative volunteers }\end{array}$ \\
\hline Fox et al., 2012 & pH1N1-09 & $\begin{array}{l}\mathrm{CD}^{+} \mathrm{T} \text { cell activation is delayed in patients severely infected with } \mathrm{pH} 1 \mathrm{~N} 1-09 \text { and } \\
\text { are lymphopenic for } \mathrm{CD}^{+}, \mathrm{CD}^{+} \mathrm{T} \text { cells, and NK cells }\end{array}$ \\
\hline Zhao et al., 2012 & pH1N1-09 & $\begin{array}{l}\text { Influenza-specific } \mathrm{CD}^{+} \mathrm{T} \text { cells responses are associated with progression to } \\
\text { severe } \mathrm{pH} 1 \mathrm{~N} 1-09 \text { infection }\end{array}$ \\
\hline Sridhar et al., 2013 & pH1N1-09 & $\begin{array}{l}\text { Pre-existing memory } \mathrm{CD}^{+} \mathrm{T} \text { cell responses from seronegative patients naturally } \\
\text { exposed to } \mathrm{pH} 1 \mathrm{~N} 1-09 \text { correlate with reduced illness severity }\end{array}$ \\
\hline Hillaire et al., 2013 & $\mathrm{sH} 1 \mathrm{~N} 1 / \mathrm{sH} 3 \mathrm{~N} 2 \rightarrow \mathrm{pH} 1 \mathrm{~N} 1-09 / \mathrm{H} 3 \mathrm{~N} 2 \mathrm{v}$ & $\begin{array}{l}\mathrm{CD}^{+} \mathrm{T} \text { cells lines generated with } \mathrm{sH} 1 \mathrm{~N} 1 \text {, sH3N2 viruses or peptides derived } \\
\text { from these strains respond to target cells infected with } \mathrm{pH} 1 \mathrm{~N} 1 \text { virus }\end{array}$ \\
\hline Van De Sandt et al., 2014 & $\mathrm{pH} 1 \mathrm{~N} 1 / \mathrm{sH} 1 \mathrm{~N} 1 / \mathrm{sH} 3 \mathrm{~N} 2 \rightarrow \mathrm{H} 7 \mathrm{~N} 9$ & $\begin{array}{l}\text { CD8 }{ }^{+} \mathrm{T} \text { cells stimulated with } \mathrm{sH} 1 \mathrm{~N} 1 \text {, sH3N2, or } \mathrm{pH} 1 \mathrm{~N} 1 \text { recognize and lyse target } \\
\text { cells infected with H7N9 }\end{array}$ \\
\hline Quinones-Parra et al., 2014 & Any human IAV including H7N9 & $\begin{array}{l}\text { CD8 }{ }^{+} T \text { cells from healthy donors expressing the HLA-A*0201, }-A * 0301 \text {, } \\
-B * 5701,-B * 1801 \text { allele, and/or } B * 0801 \text { allele(s) respond to universally conserved } \\
\text { immunogenic peptides }\end{array}$ \\
\hline
\end{tabular}

1999) resulted in superior viral clearance and reduced pathology (Flynn et al., 1998). Moreover, tertiary challenge of mice with highly lethal H7N7 resulted in recall of heterosubtypic memory $\mathrm{CD}^{+} \mathrm{T}$ cell responses (established from priming with $\mathrm{H} 1 \mathrm{~N} 1$ and then $\mathrm{H} 3 \mathrm{~N} 2$ ) that provided exceptionally enhanced virus control (within 3 days post-infection) (Christensen et al., 2000).

In comparison to $\mathrm{CD}^{+}{ }^{+} \mathrm{T}$ cells, the role of $\mathrm{CD} 4^{+} \mathrm{T}$ cells in influenza is less well understood, partly due to their heterogeneity and the lack of epitope-specific systems (Sant and McMichael, 2012). The traditionally accepted role of influenza-specific $\mathrm{CD} 4^{+}$ $\mathrm{T}$ cells is in providing help to $\mathrm{B}$ cells for the production of highquality Abs (Topham and Doherty, 1998), as their activation is dependent on recognition of peptide in the context of MHC-II on professional APCs but also have a major role in providing help for the establishment of $\mathrm{CD} 8^{+} \mathrm{T}$ cell memory, critical for a robust recall response (Sun et al., 2004). Transfer of influenza-specific effector $\mathrm{CD} 4^{+} \mathrm{T}$ cells into $\mathrm{T}$ cell-deficient mice accelerates production of neutralizing Abs, thus cross-reactive memory $\mathrm{CD}^{+}$ $\mathrm{T}$ cells can potentially enhance $\mathrm{B}$ cell responses during infection with a novel influenza virus (Scherle and Gerhard, 1986). Furthermore, depletion of $\mathrm{CD}^{+} \mathrm{T}$ cells prior to influenza challenge results in a dramatic drop of Ab titres (Eichelberger et al.,
1991), accompanied by only a small delay in virus elimination (Allan et al., 1990), driven by the remaining $\mathrm{CD}^{+} \mathrm{T}$ cell response (Topham et al., 1996; Belz et al., 2002). More recently, a comprehensive transgenic mouse study by McKinstry et al. (2012) illustrated the direct protective role of influenza-specific $\mathrm{CD} 4^{+}$ $\mathrm{T}$ cells using a series of transfer experiments into immune knockout mice (lacking FcR $\gamma$, functional IFN $\gamma$, or B cells). The authors showed that $\mathrm{CD} 4^{+} \mathrm{T}$ cells provide protection by interacting with $\mathrm{B}$ cells and $\mathrm{CD}^{+} \mathrm{T}$ cells in an IFN- $\gamma$-dependent manner. The mechanism by which $\mathrm{CD} 4^{+} \mathrm{T}$ cells are able to recognize virus-infected cells given their MHC-II restriction is yet to be deciphered. Nevertheless, in a vaccination setting of individuals receiving a split vaccine, a subset $\left(\mathrm{ICOS}^{+} \mathrm{CXCR}^{+}{ }^{+} \mathrm{CXCR}^{+}\right)$of circulating influenza-specific $\mathrm{CD} 4^{+} \mathrm{T}$ follicular helper $\left(\mathrm{T}_{\mathrm{FH}}\right)$ cells correlated with more effective $\mathrm{B}$-cell responses and greater $\mathrm{Ab}$ titres, suggesting that eliciting this type of cells could be important in inducing more effective Ab-based vaccines (Bentebibel et al., 2013).

The debate of which $\mathrm{T}$ cell subtype is more protective for influenza has been reinvigorated from recent human studies that show contrasting results (Wilkinson et al., 2012; Zhao et al., 2012; Sridhar et al., 2013). However, as evidenced from mouse studies 
outlined above, both subsets are necessary for a complete and coordinated response against influenza infection. Interestingly, in a challenge study (Wilkinson et al., 2012) with volunteers deliberately infected with $\mathrm{H} 3 \mathrm{~N} 2$, the numbers of pre-existing influenza-specific $\mathrm{CD}^{+}$, but not $\mathrm{CD}^{+}$, $\mathrm{T}$ cells were found to correlate with lower virus shedding and less severe, shorter illness. These investigators favored CD $4^{+} \mathrm{T}$ cell cytotoxicity as the possible underlying mechanism. However, in a later study investigating $\mathrm{T}$ cell immunity in $\mathrm{H} 1 \mathrm{~N} 1 \mathrm{pdm}$ virus-infected patients, $\mathrm{CD}^{+} \mathrm{T}$ cell responses were associated with more severe infection (Zhao et al., 2012). A more recent study (Sridhar et al., 2013) followed natural infection of a large cohort over the 2009 pandemic and determined pre-immune correlates with the outcome of influenza disease over the pandemic. The study showed that those individuals with established influenza-specific $\mathrm{CD}^{+} \mathrm{T}$ cell memory experienced milder illness following infection with the newly emerged virus. Although this study did not find a correlation with $\mathrm{CD}^{+} \mathrm{T}$ cell responses and disease outcome, it cannot rule out their importance. Further studies are needed to better understand immune mechanisms underlying $\mathrm{T}$ cell-mediated protection against influenza viruses.

Some experimental vaccination protocols have effectively induced protective heterosubtypic $\mathrm{T}$ cell immunity, including non-replicative, cold adapted influenza vaccine (Powell et al., 2007), and virus-like particles (Hamada et al., 2013). In addition, DNA vaccines (Ulmer et al., 1993, 1998; Fu et al., 1999), primeboost protocols (Epstein et al., 2005) and the use of adjuvants can provide and enhance $\mathrm{T}$ cell-mediated heterosubtypic protection (Chua et al., 2011, 2014). A live non-replicating vaccinia vaccine encoding the NP and M1 proteins, MVA-NP/M1, is currently being evaluated in human efficacy trials (Berthoud et al., 2011). The vaccine proved effective for human influenza challenge in a limited number of individuals, showing higher levels of influenza-specific $\mathrm{CD} 8^{+} \mathrm{T}$ cells in vaccinees, especially those displaying the HLA-A*0201 allele, compared to placebo controls correlating with reduced infection and viral shedding (Antrobus et al., 2012; Lillie et al., 2012). Furthermore, the vaccine was able to boost $\mathrm{T}$ cell immunity in those aged 65 and over, a promising result for those who need an effective vaccine the most. However, it may be difficult to convince regulatory authorities to license a $\mathrm{T}$ cell-based vaccine that still allows individuals to become infected and shed virus. If such a vaccine were to replace the current TIV, a large-scale study would need to be performed in many individuals of distinct HLAs across different ethnicities to prove effectiveness.

Thus, manipulating existing style vaccines to induce or boost $\mathrm{T}$ cell immunity could potentially lead toward development of broadly protective influenza vaccines. However, there are still considerable challenges in the development of broadly cross-reactive $\mathrm{T}$ cell-inducing vaccines, which include persistence of $\mathrm{T}$ cell memory after influenza immunization (Valkenburg et al., 2012), population protective coverage across different HLAs, vaccinemediated immune escape and immunopathology. Firstly, it is still far from clear for how long functional influenza-specific memory $\mathrm{CD}^{+} \mathrm{T}$ cells persist in humans. Studies from yellow fever and smallpox vaccination suggest that memory $\mathrm{T}$ cells can be detected from 10 years (Akondy et al., 2009) to 50 years (Miller et al., 2008) following vaccination, respectively. Yet many adults fail to control influenza infection. A vaccine study of young children found that a threshold level (of $>100$ SFU $/ 10^{6}$ PBMCs) was required for effective T cell-mediated clinical protection (Forrest et al., 2008). Therefore, the varying levels of $\mathrm{T}$ cell immunity that are likely to exist in the wider population, due to different histories of exposure to natural infection, may contribute to the spectrum of disease severity. Early studies on cytotoxic T cells in humans suggested that influenza CTL memory declines rapidly with a half life of 2-3 years (McMichael et al., 1983a). The main purpose of a $\mathrm{T}$ cell-inducing vaccine may therefore be to maintain memory $\mathrm{CD}^{+} \mathrm{T}$ cells at levels capable of achieving clinical protection, which may require booster doses every few years. The presence of co-morbidities, age-related differences of innate responses in the young and immunological decline in the elderly (reviewed by Oshansky and Thomas, 2012) could also impair $\mathrm{T}$ cell recall responses. Furthermore, an influenza T-cell based vaccine would have to address the issue HLA coverage in a diverse population and be appropriate for ethnic minorities with rare MHC alleles. This could be achieved either by utilization of peptide epitopes representing HLA-super families (Assarsson et al., 2008), or the inclusion of full-length influenza-derived proteins in a form that enables endogenous antigen processing.

\section{INFLUENZA CAN ESCAPE T CELL IMMUNITY}

If such a $\mathrm{T}$ cell-inducing vaccine could be produced, the issue of vaccine-mediated $\mathrm{T}$ cell escape, resonant of Ab-mediated antigenic drift, could theoretically become significant. RNA viruses, such as influenza, are characterized by poor fidelity of replication of their genomes, leading to the emergence of viral variants capable of rapidly adapting in response to immune selective pressure, as seen with seasonal antigenic drift. Subversion of T cell control is well documented for chronic viral infections, like HIV and HCV (Pircher et al., 1990; Moore et al., 2002; Fernandez et al., 2005) and represents one of the major obstacles for viral control and vaccine design.

Within an individual, $\mathrm{T}$ cells can select influenza escape variants as the virus replicates. We have recently described the emergence of influenza variants within $\mathrm{CD}^{+} \mathrm{T}$ cell target regions in a persistently infected, immunocompromised child, (Valkenburg et al., 2013). Additionally, $\mathrm{CD}^{+} \mathrm{T}$ cell immune escape viruses could be readily isolated from immunodeficient (B cell knockout) and immune intact wild-type mice. Surprisingly, we observed that these CTL escape variants arise early during infection by day 5, and increase in frequency and variety over the timecourse of infection. The selection of $\mathrm{CD}^{+} \mathrm{T}$ cell escape mutants was clearly driven by selective pressure as these variants revert in the absence of immune pressure in MHC-mismatched mice (Valkenburg et al., 2013). Further experiments suggested that influenza-specific escape from $\mathrm{T}$ cell responses is heavily dependent on the particular epitope and potentially the underlying characteristics of the $\mathrm{T}$ cell receptor repertoire. Interestingly, influenza viruses favored escape at the residues that anchor epitope peptides to MHC (Valkenburg et al., 2013).

The emergence of specific $\mathrm{CD} 8^{+} \mathrm{T}$ cell mutations in influenza can also be detected at a population level. Factors such as immunodominance, HLA frequency and viral fitness can impact the likelihood of emergence and selection of escape viruses (Berkhoff 
et al., 2005). Indeed, there are documented examples of naturally occurring mutations within critical $\mathrm{T}$ cell antigenic peptides leading to immune escape in individuals bearing certain HLA alleles. The Rimmelzwann group has pioneered and enhanced our knowledge of $\mathrm{CD}^{+} \mathrm{T}$ cell-mediated immune escape in human influenza. Boon et al. (2004) identified substitutions within the HLA-B*0702- and $\mathrm{B}^{*} 3501$-restricted $\mathrm{NP}_{418-426}$ epitope that could either result in cross-reactivity, or in some cases, in immune escape. Further immunological and structural characterization of the $\mathrm{NP}_{418-426}$ variants from 1918 to 2009 revealed that mutations in solvent-exposed, potentially TCR contact residues, result in immune escape (Gras et al., 2010). At the same time, we confirmed the presence of cross-reactive CTL populations that reacted against a wider spectrum of $\mathrm{NP}_{418-426}$ variants (Gras et al., 2010). The identification of epitopes recognized by such populations, and the key residues for TCR recognition within them, may be critical information for producing a vaccine capable of eliciting cross-reactive $\mathrm{T}$ cells to provide coverage against the wide spectrum of influenza antigenic variation, an idea that we have pioneered using the B6 mouse model of influenza infections (Valkenburg et al., 2013). Conversely, CD4 ${ }^{+} \mathrm{T}$ cell-mediated viral escape in influenza has received considerably less attention and the selection of $\mathrm{CD}^{+}$T cell escape peptide variants has not currently been demonstrated, either within an individual or across a population.

In earlier work examining drift in the viral NP at a population level, Voeten et al. (2000) identified mutations in HLA-B*2705restricted $\mathrm{NP}_{383-391}$ epitope and HLA-B*08:01-NP $380-388$ resulting in immune escape. The NP-R384K mutation at an MHC-I anchor residue, which resulted in a loss of $\mathrm{CD}^{+} \mathrm{T}$ cell recognition, was initially detected in 1990 and later in 1993 as R384G. The escape mutant quickly replaced the wild-type sequence in H3N2 viruses (Gog et al., 2003), resulting in a loss of immunogenicity in the population expressing the HLA-B27 allele. Further characterization of this mutant indicated that the escape was driven by CTL selective pressure as the mutation imposed a fitness cost that had to be compensated for by additional mutations in flanking regions (Rimmelzwaan et al., 2005). More recently, a CTL escape variant within the HLA-A*0101-restricted $\mathrm{NP}_{44-52}$ in the novel H7N9 virus has been reported (QuinonesParra et al., 2014; Van De Sandt et al., 2014), with structural data indicating that substitution in an MHC-I anchor residue of the peptide epitope compromised peptide-MHC-I complex stability and thus accessibility to CTLs (Quinones-Parra et al., 2014).

Although immunodominant T cells may generate escape variants, they remain a hugely valuable tool in the arsenal for combating influenza infection. It may be possible to pre-empt escape by priming the $\mathrm{T}$ cell repertoire against a variety of dominant mutants at TCR contact sites (Valkenburg et al., 2013) or possibly stabilizing the MHC for low affinity anchor mutants. The NP protein, though capable of harboring $\mathrm{T}$ cell escape mutations, is one of the most immunogenic influenza proteins for $\mathrm{T}$ cells (Grant et al., 2013). Fortunately, the NP of LAIV can be substituted to represent the current NP or the NP of escape variants without affecting the viral growth or vaccine immunogenicity (Isakova-Sivak et al., 2011).

\section{INNATE T CELLS FOR INFLUENZA VIRUS INFECTION}

Until now this review has discussed adaptive immunity to influenza, however another component, innate $\mathrm{T}$ cells, have potential use for subverting infection due to innate receptors recognizing conserved universal motifs. The non-conventional or innate $\mathrm{T}$ cell compartment comprises of $\gamma \delta \mathrm{T}$ cells, CD1drestricted invariant natural killer $\mathrm{T}$ cells (iNKT), and MR1restricted Mucosal-associated invariant T (MAIT) cells. This compartment constitutively expresses high levels of the C-type lectin, CD161. Innate $\mathrm{T}$ cells can be activated by a diverse range of ligands, either endogenous $(\beta$-GlcCer and iGB3 for NKT; MICA/B for $\gamma \delta$ T cells) and exogenous (phosphoantigens and bisphosphonates for $\gamma \delta$ T cells, $\alpha$-GalCer-for iNKT, bacterial lipids for NKT and metabolites for MAIT cells) (Kjer-Nielsen et al., 2012; Rossjohn et al., 2012; Born et al., 2013). Upon TCR recognition of their cognate antigen or by cytokine driven signals, innate $\mathrm{T}$ cells can rapidly produce an array of inflammatory and effector molecules (IFN $\gamma$, TNF, IL-17, IL-4, IL-22, perforin, granzyme $\mathrm{B}, \mathrm{MIP}-1 \beta$ ). In humans, innate $\mathrm{T}$ cells can comprise up to $30 \%$ of the peripheral blood $\mathrm{CD}^{+} \mathrm{T}$ cell compartment, and are also enriched at mucosal sites including lung, intestine and liver. Given their location, potent inflammatory and cytolytic function, innate $\mathrm{T}$ cells are potentially important players during IAV infection. Although their role is well studied in autoimmunity, cancer, and chronic viral infections such as HIV-1, (Berzins et al., 2011; Cosgrove et al., 2013; Leeansyah et al., 2013; Vantourout and Hayday, 2013), there is a paucity of data on how innate $\mathrm{T}$ cells contribute to combating influenza infection.

Several studies in humans have demonstrated that a major subset of human $\gamma \delta \mathrm{T}$ cells $(\mathrm{V} \gamma 9 \mathrm{~V} \delta 2)$ can directly kill human and avian origin influenza-infected macrophages and lung alveolar epithelial cells in vitro (Qin et al., 2009; Tu et al., 2011; Li et al., 2013). Further studies in humanized mice have shown that vaccination with aminobisphosphonate pamidronate (PAM) can activate the $\mathrm{V} \gamma 9 \mathrm{~V} \delta 2$ subset, and that $\mathrm{V} \gamma 9 \mathrm{~V} \delta 2 \mathrm{~T}$ cells can inhibit viral replication and dampen inflammatory responses in the lung (Tu et al., 2011). Thus, pre-arming $\gamma \delta \mathrm{T}$ cells may also be beneficial in human IAV infection as an alternative antiviral strategy (Tu et al., 2011).

Similarly, endogenous iNKT cells have been shown to have an immunoregulatory role in IAV. From adoptive transfer studies in C57BL/6 mice, iNKT cells have been demonstrated to alleviate bronchopneumonia and its associated pathology in $\mathrm{J} \alpha 18^{-/-}$ (iNKT deficient) mice infected with highly virulent H3N2 (Paget et al., 2011; Kok et al., 2012). Both endogenous and exogenous ( $\alpha$-GalCer) activation of iNKT aids in the development of influenza-specific $\mathrm{CD}^{+} \mathrm{T}$ cells by promoting their survival (Guillonneau et al., 2009) and the maturation of APCs that present epitopes to influenza-specific $\mathrm{CD}^{+} \mathrm{T}$ cells (Paget et al., 2011). Additionally, iNKT-derived cytokines, such as IL-33 and IL-22, produced during IAV infection have been associated with regulation of eosinophil maturation in an IL-5-dependent manner and protection of the airway epithelium, respectively (Paget et al., 2012; Gorski et al., 2013). These studies demonstrate that iNKT can aid in the maturation of both the influenza-specific adaptive and the innate response, and therefore may be important subsets to induce in a universal IAV vaccine. 
Although the majority of these studies highlight the immunoregulatory role of murine innate $\mathrm{T}$ cells in models of IAV, more studies are needed in humans to investigate whether these and other non-conventional innate $\mathrm{T}$ cells may contribute to influenza-specific adaptive immune effectors and thus be of benefit to induce in a universal IAV vaccine.

\section{CONCLUSIONS}

Although the current Ab-mediated vaccines are the most cost effective way to combat the yearly influenza epidemics, they are strain-specific and thus need to be updated annually while providing little or no protection from novel outbreak strains. Furthermore, during the 2009 pandemic, it took several months to produce and test the newly made $\mathrm{H} 1 \mathrm{~N} 1 \mathrm{pdm}$-specific influenza vaccine, which meant it was only available after the peak of influenza activity. Thus, there is an urgent need to develop novel approaches for a universal influenza vaccine that has broad reactivity across a diversity of influenza strains and subtypes. Ideally, this vaccine would elicit both broadly cross-reactive Abs directed at highly conserved yet sub-dominant targets such as the HA stalk, which are currently proving highly effective in mouse studies. Furthermore, the ideal vaccine would also elicit a robust $\mathrm{T}$ cell response with long-term memory potential, recognizing epitopes derived from conserved and immunogenic internal proteins. Recent data on both universal Abs and $\mathrm{T}$ cell responses against influenza are promising, but more research still needs to be done to provide insights into the longevity and effectiveness of this type of immunity. The possibility of generating escape mutants by widespread use of vaccines designed to elicit such cross-reactive responses needs to be understood as well as the potential impact on virus evolution.

\section{ACKNOWLEDGMENTS}

Sergio Quiñones-Parra is a recipient of the University of Melbourne International Research Scholarship and a CONACyT Scholar. Sophie A. Valkenburg and Liyen Loh are National Health and Medical Research Council of Australia (NHMRC) CJ Martin Fellows, Katherine Kedzierska is an NHMRC Level 2 Career Development Fellow. The work was supported by an NHMRC Program Grant to LEB (AI APP567122).

\section{REFERENCES}

Akondy, R. S., Monson, N. D., Miller, J. D., Edupuganti, S., Teuwen, D., Wu, H., et al. (2009). The yellow fever virus vaccine induces a broad and polyfunctional human memory CD8+ T cell response. J. Immunol. 183, 7919-7930. doi: 10.4049/jimmunol.0803903

Allan, W., Tabi, Z., Cleary, A., and Doherty, P. C. (1990). Cellular events in the lymph node and lung of mice with influenza. Consequences of depleting CD4+ T cells. J. Immunol. 144, 3980-3986.

Antrobus, R. D., Lillie, P. J., Berthoud, T. K., Spencer, A. J., McLaren, J. E., Ladell, K., et al. (2012). A T cell-inducing influenza vaccine for the elderly: safety and immunogenicity of MVA-NP+M1 in adults aged over 50 years. PLoS ONE 7:e48322. doi: 10.1371/journal.pone.0048322

Askonas, B. A., Taylor, P. M., and Esquivel, F. (1988). Cytotoxic T cells in influenza infection. Ann. N.Y. Acad. Sci. 532, 230-237. doi: 10.1111/j.17496632.1988.tb36342.x

Assarsson, E., Bui, H. H., Sidney, J., Zhang, Q., Glenn, J., Oseroff, C., et al. (2008). Immunomic analysis of the repertoire of T-cell specificities for influenza A virus in humans. J. Virol. 82, 12241-12251. doi: 10.1128/JVI.01 563-08
Belz, G. T., Wodarz, D., Diaz, G., Nowak, M. A., and Doherty, P. C. (2002). Compromised influenza virus-specific CD8(+)-T-cell memory in CD4(+)-Tcell-deficient mice. J. Virol. 76, 12388-12393. doi: 10.1128/JVI.76.23.1238812393.2002

Bender, B. S., Croghan, T., Zhang, L., and Small, P. A. Jr. (1992). Transgenic mice lacking class I major histocompatibility complex-restricted $\mathrm{T}$ cells have delayed viral clearance and increased mortality after influenza virus challenge. J. Exp. Med. 175, 1143-1145. doi: 10.1084/jem.175.4.1143

Bentebibel, S. E., Lopez, S., Obermoser, G., Schmitt, N., Mueller, C., Harrod, C., et al. (2013). Induction of ICOS+CXCR3+CXCR5+ TH cells correlates with antibody responses to influenza vaccination. Sci. Transl. Med. 5:176ra132. doi: 10.1126/scitranslmed.3005191

Berkhoff, E. G., De Wit, E., Geelhoed-Mieras, M. M., Boon, A. C., Symons, J., Fouchier, R. A., et al. (2005). Functional constraints of influenza A virus epitopes limit escape from cytotoxic T lymphocytes. J. Virol. 79, 11239-11246. doi: 10.1128/JVI.79.17.11239-11246.2005

Berthoud, T. K., Hamill, M., Lillie, P. J., Hwenda, L., Collins, K. A., Ewer, K. J., et al. (2011). Potent CD8+ T-cell immunogenicity in humans of a novel heterosubtypic influenza A vaccine, MVA-NP+M1. Clin. Infect. Dis. 52, 1-7. doi: 10.1093/cid/ciq015

Berzins, S. P., Smyth, M. J., and Baxter, A. G. (2011). Presumed guilty: natural killer $\mathrm{T}$ cell defects and human disease. Nat. Rev. Immunol. 11, 131-142. doi: $10.1038 /$ nri2904

Bodewes, R., Fraaij, P. L., Geelhoed-Mieras, M. M., Van Baalen, C. A., Tiddens, H. A., Van Rossum, A. M., et al. (2011). Annual vaccination against influenza virus hampers development of virus-specific CD8 $(+) \mathrm{T}$ cell immunity in children. J. Virol. 85, 11995-12000. doi: 10.1128/JVI.05213-11

Bodewes, R., Kreijtz, J. H., Hillaire, M. L., Geelhoed-Mieras, M. M., Fouchier, R. A., Osterhaus, A. D., et al. (2010). Vaccination with whole inactivated virus vaccine affects the induction of heterosubtypic immunity against influenza virus $\mathrm{A} / \mathrm{H} 5 \mathrm{~N} 1$ and immunodominance of virus-specific CD8+ T-cell responses in mice. J. Gen. Virol. 91, 1743-1753. doi: 10.1099/vir.0. 020784-0

Boon, A. C., De Mutsert, G., Van Baarle, D., Smith, D. J., Lapedes, A. S., Fouchier, R. A., et al. (2004). Recognition of homo- and heterosubtypic variants of influenza A viruses by human CD8+ T lymphocytes. J. Immunol. 172, 2453-2460. doi: 10.4049/jimmunol.172.4.2453

Born, W. K., Kemal Aydintug, M., and O’Brien, R. L. (2013). Diversity of gammadelta T-cell antigens. Cell. Mol. Immunol. 10, 13-20. doi: 10.1038/cmi. 2012.45

Braciale, T. J. (1977). Immunologic recognition of influenza virus-infected cells. II. Expression of influenza A matrix protein on the infected cell surface and its role in recognition by cross-reactive cytotoxic T cells. J. Exp. Med. 146, 673-689. doi: 10.1084/jem.146.3.673

Carragher, D. M., Kaminski, D. A., Moquin, A., Hartson, L., and Randall, T. D. (2008). A novel role for non-neutralizing antibodies against nucleoprotein in facilitating resistance to influenza virus. J. Immunol. 181, 4168-4176. doi: 10.4049/jimmunol.181.6.4168

Christensen, J. P., Doherty, P. C., Branum, K. C., and Riberdy, J. M. (2000). Profound protection against respiratory challenge with a lethal H7N7 influenza A virus by increasing the magnitude of CD8 $(+)$ T-cell memory. J. Virol. 74, 11690-11696. doi: 10.1128/JVI.74.24.11690-11696.2000

Chua, B. Y., Olson, M. R., Bedoui, S., Sekiya, T., Wong, C. Y., Turner, S. J., et al. (2014). The use of a TLR2 agonist-based adjuvant for enhancing effector and memory CD8 T-cell responses. Immunol. Cell Biol. 92, 377-383. doi: 10.1038/icb.2013.102

Chua, B. Y., Pejoski, D., Turner, S. J., Zeng, W., and Jackson, D. C. (2011). Soluble proteins induce strong CD8 $+\mathrm{T}$ cell and antibody responses through electrostatic association with simple cationic or anionic lipopeptides that target TLR2. J. Immunol. 187, 1692-1701. doi: 10.4049/jimmunol.1100486

Corti, D., and Lanzavecchia, A. (2013). Broadly neutralizing antiviral antibodies. Annu. Rev. Immunol. 31, 705-742. doi: 10.1146/annurev-immunol-032712095916

Corti, D., Suguitan, A. L. Jr., Pinna, D., Silacci, C., Fernandez-Rodriguez, B. M., Vanzetta, F., et al. (2010). Heterosubtypic neutralizing antibodies are produced by individuals immunized with a seasonal influenza vaccine. J. Clin. Invest. 120, 1663-1673. doi: 10.1172/JCI41902

Corti, D., Voss, J., Gamblin, S. J., Codoni, G., Macagno, A., Jarrossay, D., et al. (2011). A neutralizing antibody selected from plasma cells that binds to group 1 
and group 2 influenza A hemagglutinins. Science 333, 850-856. doi: 10.1126/science. 1205669

Cosgrove, C., Ussher, J. E., Rauch, A., Gartner, K., Kurioka, A., Huhn, M. H., et al. (2013). Early and nonreversible decrease of CD161++ /MAIT cells in HIV infection. Blood 121, 951-961. doi: 10.1182/blood-2012-06-436436

DiLillo, D. J., Tan, G. S., Palese, P., and Ravetch, J. V. (2014). Broadly neutralizing hemagglutinin stalk-specific antibodies require FcgammaR interactions for protection against influenza virus in vivo. Nat. Med. 20, 143-151. doi: 10.1038/nm.3443

Dougan, S. K., Ashour, J., Karssemeijer, R. A., Popp, M. W., Avalos, A. M., Barisa, M., et al. (2013). Antigen-specific B-cell receptor sensitizes B cells to infection by influenza virus. Nature 503, 406-409. doi: 10.1038/nature 12637

Dreyfus, C., Laursen, N. S., Kwaks, T., Zuijdgeest, D., Khayat, R., Ekiert, D. C., et al. (2012). Highly conserved protective epitopes on influenza B viruses. Science 337, 1343-1348. doi: 10.1126/science. 1222908

Eichelberger, M. C., Wang, M. L., Allan, W., Webster, R. G., and Doherty, P. C. (1991). Influenza virus RNA in the lung and lymphoid tissue of immunologically intact and CD4-depleted mice. J. Gen. Virol. 72(pt 7), 1695-1698. doi: 10.1099/0022-1317-72-7-1695

Ekiert, D. C., Bhabha, G., Elsliger, M. A., Friesen, R. H., Jongeneelen, M., Throsby, M., et al. (2009). Antibody recognition of a highly conserved influenza virus epitope. Science 324, 246-251. doi: 10.1126/science.1171491

Ekiert, D. C., Friesen, R. H., Bhabha, G., Kwaks, T., Jongeneelen, M., Yu, W., et al. (2011). A highly conserved neutralizing epitope on group 2 influenza A viruses. Science 333, 843-850. doi: 10.1126/science.1204839

Ekiert, D. C., Kashyap, A. K., Steel, J., Rubrum, A., Bhabha, G., Khayat, R., et al. (2012). Cross-neutralization of influenza A viruses mediated by a single antibody loop. Nature 489, 526-532. doi: 10.1038/nature11414

Elhefnawi, M., Alaidi, O., Mohamed, N., Kamar, M., El-Azab, I., Zada, S., et al. (2011). Identification of novel conserved functional motifs across most Influenza A viral strains. Virol. J. 8:44. doi: 10.1186/1743-422X-8-44

Epstein, S. L. (2006). Prior H1N1 influenza infection and susceptibility of Cleveland Family Study participants during the H2N2 pandemic of 1957: an experiment of nature. J. Infect. Dis. 193, 49-53. doi: 10.1086/498980

Epstein, S. L., Kong, W. P., Misplon, J. A., Lo, C. Y., Tumpey, T. M., Xu, L., et al. (2005). Protection against multiple influenza A subtypes by vaccination with highly conserved nucleoprotein. Vaccine 23, 5404-5410. doi: 10.1016/j.vaccine.2005.04.047

Epstein, S. L., Lo, C. Y., Misplon, J. A., and Bennink, J. R. (1998). Mechanism of protective immunity against influenza virus infection in mice without antibodies. J. Immunol. 160, 322-327.

Fernandez, C., Stratov, I., De Rose, R., Walsh, K., Dale, C., Smith, M., et al. (2005). Rapid viral escape at an immunodominant simian-human immunodeficiency virus cytotoxic T-lymphocyte epitope exacts a dramatic fitness cost. J. Virol. 79, 5721-5731. doi: 10.1128/JVI.79.9.5721-5731.2005

Flynn, K. J., Belz, G. T., Altman, J. D., Ahmed, R., Woodland, D. L., and Doherty, P. C. (1998). Virus-specific CD8+ T cells in primary and secondary influenza pneumonia. Immunity 8, 683-691. doi: 10.1016/S1074-7613(00)80573-7

Flynn, K. J., Riberdy, J. M., Christensen, J. P., Altman, J. D., and Doherty, P. C. (1999). In vivo proliferation of naive and memory influenza-specific CD8 $(+)$ T cells. Proc. Natl. Acad. Sci. U.S.A. 96, 8597-8602. doi: 10.1073/pnas.96. 15.8597

Forrest, B. D., Pride, M. W., Dunning, A. J., Capeding, M. R., Chotpitayasunondh, T., Tam, J. S., et al. (2008). Correlation of cellular immune responses with protection against culture-confirmed influenza virus in young children. Clin. Vaccine Immunol. 15, 1042-1053. doi: 10.1128/CVI.00397-07

Fox, A., Le, N. M., Horby, P., Van Doorn, H. R., Nguyen, V. T., Nguyen, H. H., et al. (2012). Severe pandemic H1N1 2009 infection is associated with transient NK and T deficiency and aberrant CD8 responses. PLoS One 7:e31535. doi: 10.1371/journal.pone.0031535

Fu, T. M., Guan, L., Friedman, A., Schofield, T. L., Ulmer, J. B., Liu, M. A., et al. (1999). Dose dependence of CTL precursor frequency induced by a DNA vaccine and correlation with protective immunity against influenza virus challenge. J. Immunol. 162, 4163-4170.

Gog, J., Rimmelzwaan, G., Osterhaus, A., and Grenfell, B. (2003). Population dynamics of rapid fixation in cytotoxic $T$ lymphocyte escape mutants of influenza A. Proc. Natl. Acad. Sci. U.S.A. 100, 11143-11147. doi: 10.1073/pnas. 1830296100
Gorski, S. A., Hahn, Y. S., and Braciale, T. J. (2013). Group 2 innate lymphoid cell production of IL-5 is regulated by NKT cells during influenza virus infection. PLoS Pathog. 9:e1003615. doi: 10.1371/journal.ppat.1003615

Gotch, F., Mcmichael, A., and Rothbard, J. (1988). Recognition of influenza A matrix protein by HLA-A2-restricted cytotoxic T lymphocytes. Use of analogues to orientate the matrix peptide in the HLA-A2 binding site. J. Exp. Med. 168, 2045-2057. doi: 10.1084/jem.168.6.2045

Graham, M. B., and Braciale, T. J. (1997). Resistance to and recovery from lethal influenza virus infection in B lymphocyte-deficient mice. J. Exp. Med. 186, 2063-2068. doi: 10.1084/jem.186.12.2063

Grant, E., Wu, C., Chan, K. F., Eckle, S., Bharadwaj, M., Zou, Q. M., et al. (2013). Nucleoprotein of influenza A virus is a major target of immunodominant CD8+ T-cell responses. Immunol. Cell Biol. 91, 184-194. doi: 10.1038/icb.2012.78

Gras, S., Kedzierski, L., Valkenburg, S. A., Laurie, K., Liu, Y. C., Denholm, J. T., et al. (2010). Cross-reactive CD8 + T-cell immunity between the pandemic H1N12009 and H1N1-1918 influenza A viruses. Proc. Natl. Acad. Sci. U.S.A. 107, 12599-12604. doi: 10.1073/pnas.1007270107

Graves, P. N., Schulman, J. L., Young, J. F., and Palese, P. (1983). Preparation of influenza virus subviral particles lacking the HAl subunit of hemagglutinin: unmasking of cross-reactive HA2 determinants. Virology 126, 106-116. doi: 10.1016/0042-6822(83)90465-8

Greenbaum, J. A., Kotturi, M. F., Kim, Y., Oseroff, C., Vaughan, K., Salimi, N., et al. (2009). Pre-existing immunity against swine-origin H1N1 influenza viruses in the general human population. Proc. Natl. Acad. Sci. U.S.A. 106, 20365-20370. doi: 10.1073/pnas.0911580106

Guillonneau, C., Mintern, J. D., Hubert, F. X., Hurt, A. C., Besra, G. S., Porcelli, S., et al. (2009). Combined NKT cell activation and influenza virus vaccination boosts memory CTL generation and protective immunity. Proc. Natl. Acad. Sci. U.S.A. 106, 3330-3335. doi: 10.1073/pnas.0813309106

Hamada, H., Bassity, E., Flies, A., Strutt, T. M., Garcia-Hernandez Mde, L., McKinstry, K. K., et al. (2013). Multiple redundant effector mechanisms of CD8+ T cells protect against influenza infection. J. Immunol. 190, 296-306. doi: 10.4049/jimmunol.1200571

He, X. S., Holmes, T. H., Zhang, C., Mahmood, K., Kemble, G. W., Lewis, D. B., et al. (2006). Cellular immune responses in children and adults receiving inactivated or live attenuated influenza vaccines. J. Virol. 80, 11756-11766. doi: 10.1128/JVI.01460-06

Hillaire, M. L., Vogelzang-Van Trierum, S. E., Kreijtz, J. H., De Mutsert, G., Fouchier, R. A., Osterhaus, A. D., et al. (2013). Human T-cells directed to seasonal influenza A virus cross-react with 2009 pandemic influenza A (H1N1) and swine-origin triple-reassortant $\mathrm{H} 3 \mathrm{~N} 2$ influenza viruses. J. Gen. Virol. 94, 583-592. doi: 10.1099/vir.0.048652-0

Isakova-Sivak, I., Chen, L. M., Matsuoka, Y., Voeten, J. T., Kiseleva, I., Heldens, J. G., et al. (2011). Genetic bases of the temperature-sensitive phenotype of a master donor virus used in live attenuated influenza vaccines: A/Leningrad/134/17/57 (H2N2). Virology 412, 297-305. doi: 10.1016/j.virol.2011.01.004

Jegaskanda, S., Amarasena, T. H., Laurie, K. L., Tan, H. X., Butler, J., Parsons, M. S., et al. (2013a). Standard trivalent influenza virus protein vaccination does not prime antibody-dependent cellular cytotoxicity in macaques. J. Virol. 87, 13706-13718. doi: 10.1128/JVI.01666-13

Jegaskanda, S., Job, E. R., Kramski, M., Laurie, K., Isitman, G., De Rose, R., et al. (2013b). Cross-reactive influenza-specific antibody-dependent cellular cytotoxicity antibodies in the absence of neutralizing antibodies. J. Immunol. 190, 1837-1848. doi: 10.4049/jimmunol.1201574

Kanekiyo, M., Wei, C. J., Yassine, H. M., McTamney, P. M., Boyington, J. C., Whittle, J. R., et al. (2013). Self-assembling influenza nanoparticle vaccines elicit broadly neutralizing H1N1 antibodies. Nature 499, 102-106. doi: 10.1038/nature12202

Kees, U., and Krammer, P. H. (1984). Most influenza A virus-specific memory cytotoxic $\mathrm{T}$ lymphocytes react with antigenic epitopes associated with internal virus determinants. J. Exp. Med. 159, 365-377. doi: 10.1084/jem.159.2.365

Khurana, S., Loving, C. L., Manischewitz, J., King, L. R., Gauger, P. C., Henningson, J., et al. (2013). Vaccine-induced anti-HA2 antibodies promote virus fusion and enhance influenza virus respiratory disease. Sci. Transl. Med. 5:200ra114. doi: 10.1126/scitranslmed.3006366

Kjer-Nielsen, L., Patel, O., Corbett, A. J., Le Nours, J., Meehan, B., Liu, L., et al. (2012). MR1 presents microbial vitamin B metabolites to MAIT cells. Nature 491, 717-723. doi: 10.1038/nature11605

Kok, W. L., Denney, L., Benam, K., Cole, S., Clelland, C., McMichael, A. J., et al. (2012). Pivotal Advance: Invariant NKT cells reduce accumulation of 
inflammatory monocytes in the lungs and decrease immune-pathology during severe influenza A virus infection. J. Leukoc. Biol. 91, 357-368. doi: 10.1189/jlb.0411184

Krammer, F., Margine, I., Hai, R., Flood, A., Hirsh, A., Tsvetnitsky, V., et al. (2013). $\mathrm{H} 3$ stalk-based chimeric hemagglutinin influenza virus constructs protect mice from H7N9 challenge. J. Virol. 88, 2340-2343. doi: 10.1128/JVI.00641-13

Krammer, F., Pica, N., Hai, R., Tan, G. S., and Palese, P. (2012). Hemagglutinin stalk-reactive antibodies are boosted following sequential infection with seasonal and pandemic H1N1 Influenza virus in mice. J. Virol. 86, 10302-10307. doi: 10.1128/JVI.01336-12

Kreijtz, J. H., De Mutsert, G., Van Baalen, C. A., Fouchier, R. A., Osterhaus, A. D., and Rimmelzwaan, G. F. (2008). Cross-recognition of avian H5N1 influenza virus by human cytotoxic $\mathrm{T}$ lymphocyte populations directed to human influenza A virus. J. Virol. 82, 5161-5166 doi: 10.1128/JVI.02694-07

Lamere, M. W., Lam, H. T., Moquin, A., Haynes, L., Lund, F. E., Randall, T. D., et al. (2011). Contributions of antinucleoprotein IgG to heterosubtypic immunity against influenza virus. J. Immunol. 186, 4331-4339. doi: 10.4049/jimmunol.1003057

Lee, L. Y., Ha Do, L. A., Simmons, C., De Jong, M. D., Chau, N. V., Schumacher, R., et al. (2008). Memory T cells established by seasonal human influenza A infection cross-react with avian influenza A (H5N1) in healthy individuals. J. Clin. Invest. 118, 3478-3490. doi: 10.1172/JCI32460

Leeansyah, E., Ganesh, A., Quigley, M. F., Sonnerborg, A., Andersson, J., Hunt, P. W., et al. (2013). Activation, exhaustion, and persistent decline of the antimicrobial MR1-restricted MAIT-cell population in chronic HIV-1 infection. Blood 121, 1124-1135. doi: 10.1182/blood-2012-07-445429

Li, H., Xiang, Z., Feng, T., Li, J., Liu, Y., Fan, Y., et al. (2013). Human Vgamma9Vdelta2-T cells efficiently kill influenza virus-infected lung alveolar epithelial cells. Cell. Mol. Immunol. 10, 159-164. doi: 10.1038/cmi.2012.70

Lillie, P. J., Berthoud, T. K., Powell, T. J., Lambe, T., Mullarkey, C., Spencer, A. J., et al. (2012). Preliminary assessment of the efficacy of a T-cell-based influenza vaccine, MVA-NP+M1, in humans. Clin. Infect. Dis. 55, 19-25. doi: $10.1093 / \mathrm{cid} / \mathrm{cis} 327$

Margine, I., Hai, R., Albrecht, R. A., Obermoser, G., Harrod, A. C., Banchereau, J., et al. (2013). H3N2 influenza virus infection induces broadly reactive hemagglutinin stalk antibodies in humans and mice. J. Virol. 87, 4728-4737. doi: 10.1128/JVI.03509-12

Marshall, D. R., Olivas, E., Andreansky, S., La Gruta, N. L., Neale, G. A., Gutierrez, A., et al. (2005). Effector CD8 + T cells recovered from an influenza pneumonia differentiate to a state of focused gene expression. Proc. Natl. Acad. Sci. U.S.A. 102, 6074-6079. doi: 10.1073/pnas.0501960102

McKinstry, K. K., Strutt, T. M., Kuang, Y., Brown, D. M., Sell, S., Dutton, R. W., et al. (2012). Memory CD4+ T cells protect against influenza through multiple synergizing mechanisms. J. Clin. Invest. 122, 2847-2856. doi: 10.1172/JCI 63689

McMichael, A. J., Gotch, F. M., Dongworth, D. W., Clark, A., and Potter, C. W. (1983a). Declining T-cell immunity to influenza, 1977-82. Lancet 2, 762-764. doi: 10.1016/S0140-6736(83)92297-3

McMichael, A. J., Gotch, F. M., Noble, G. R., and Beare, P. A. (1983b). Cytotoxic T-cell immunity to influenza. N. Engl. J. Med. 309, 13-17. doi: 10.1056/NEJM198307073090103

Miller, J. D., Van Der Most, R. G., Akondy, R. S., Glidewell, J. T., Albott, S., Masopust, D., et al. (2008). Human effector and memory CD8+ T cell responses to smallpox and yellow fever vaccines. Immunity 28, 710-722. doi: 10.1016/j.immuni.2008.02.020

Monto, A. S., Ohmit, S. E., Petrie, J. G., Johnson, E., Truscon, R., Teich, E., et al. (2009). Comparative efficacy of inactivated and live attenuated influenza vaccines. N. Engl. J. Med. 361, 1260-1267. doi: 10.1056/NEJMoa0808652

Moore, C., John, M., James, I., Christiansen, F., Witt, C., and Mallal, S. (2002). Evidence of HIV-1 adaptation to HLA-restricted immune responses at a population level. Science 296, 1439-1443. doi: 10.1126/science.1069660

Mozdzanowska, K., Feng, J., Eid, M., Kragol, G., Cudic, M., Otvos, L., et al. (2003). Induction of influenza type A virus-specific resistance by immunization of mice with a synthetic multiple antigenic peptide vaccine that contains ectodomains of matrix protein 2. Vaccine 21, 2616-2626. doi: 10.1016/S0264-410X(03) 00040-9

Neirynck, S., Deroo, T., Saelens, X., Vanlandschoot, P., Jou, W. M., and Fiers, W. (1999). A universal influenza A vaccine based on the extracellular domain of the M2 protein. Nat. Med. 5, 1157-1163. doi: 10.1038/13484
Okuno, Y., Isegawa, Y., Sasao, F., and Ueda, S. (1993). A common neutralizing epitope conserved between the hemagglutinins of influenza A virus $\mathrm{H} 1$ and $\mathrm{H} 2$ strains. J. Virol. 67, 2552-2558.

Oshansky, C. M., and Thomas, P. G. (2012). The human side of influenza. J. Leukoc. Biol. 92, 83-96. doi: 10.1189/jlb.1011506

Paget, C., Ivanov, S., Fontaine, J., Blanc, F., Pichavant, M., Renneson, J., et al. (2011). Potential role of invariant NKT cells in the control of pulmonary inflammation and CD8 $+\mathrm{T}$ cell response during acute influenza A virus $\mathrm{H} 3 \mathrm{~N} 2$ pneumonia. J. Immunol. 186, 5590-5602. doi: 10.4049/jimmunol.1002348

Paget, C., Ivanov, S., Fontaine, J., Renneson, J., Blanc, F., Pichavant, M., et al. (2012). Interleukin-22 is produced by invariant natural killer $\mathrm{T}$ lymphocytes during influenza A virus infection: potential role in protection against lung epithelial damages. J. Biol. Chem. 287, 8816-8829. doi: 10.1074/jbc.M111.304758

Pircher, H., Moskophidis, D., Rohrer, U., Burki, K., Hengartner, H., and Zinkernagel, R. (1990). Viral escape by selection of cytotoxic T cell-resistant virus variants in vivo. Nature 346, 629-633. doi: 10.1038/346629a0

Powell, T. J., Strutt, T., Reome, J., Hollenbaugh, J. A., Roberts, A. D., Woodland, D. L., et al. (2007). Priming with cold-adapted influenza A does not prevent infection but elicits long-lived protection against supralethal challenge with heterosubtypic virus. J. Immunol. 178, 1030-1038. doi: 10.4049/jimmunol.178. 2.1030

Qin, G., Mao, H., Zheng, J., Sia, S. F., Liu, Y., Chan, P. L., et al. (2009). Phosphoantigen-expanded human gammadelta $\mathrm{T}$ cells display potent cytotoxicity against monocyte-derived macrophages infected with human and avian influenza viruses. J. Infect. Dis. 200, 858-865. doi: 10.1086/605413

Quinones-Parra, S., Grant, E., Loh, L., Nguyen, T. H., Campbell, K. A., Tong, S. Y., et al. (2014). Preexisting CD8+ T-cell immunity to the H7N9 influenza A virus varies across ethnicities. Proc. Natl. Acad. Sci. U.S.A. 111, 1049-1054. doi: $10.1073 /$ pnas.1322229111

Rimmelzwaan, G. F., Berkhoff, E. G., Nieuwkoop, N. J., Smith, D. J., Fouchier, R. A., and Osterhaus, A. D. (2005). Full restoration of viral fitness by multiple compensatory co-mutations in the nucleoprotein of influenza A virus cytotoxic T-lymphocyte escape mutants. J. Gen. Virol. 86, 1801-1805. doi: 10.1099/vir.0.80867-0

Rossjohn, J., Pellicci, D. G., Patel, O., Gapin, L., and Godfrey, D. I. (2012). Recognition of CD1d-restricted antigens by natural killer T cells. Nat. Rev. Immunol. 12, 845-857. doi: 10.1038/nri3328

Sant, A. J., and McMichael, A. (2012). Revealing the role of CD4(+) T cells in viral immunity. J. Exp. Med. 209, 1391-1395. doi: 10.1084/jem.20121517

Scherle, P. A., and Gerhard, W. (1986). Functional analysis of influenza-specific helper $\mathrm{T}$ cell clones in vivo. $\mathrm{T}$ cells specific for internal viral proteins provide cognate help for B cell responses to hemagglutinin. J. Exp. Med. 164, 1114-1128. doi: 10.1084/jem.164.4.1114

Sridhar, S., Begom, S., Bermingham, A., Hoschler, K., Adamson, W., Carman, W., et al. (2013). Cellular immune correlates of protection against symptomatic pandemic influenza. Nat. Med. 19, 1305-1312. doi: 10.1038/nm.3350

Steel, J., Lowen, A. C., Wang, T. T., Yondola, M., Gao, Q., Haye, K., et al. (2010). Influenza virus vaccine based on the conserved hemagglutinin stalk domain. MBio. 1, 1-9. doi: 10.1128/mBio.00018-10

Sukeno, N., Otsuki, Y., Konno, J., Yamane, N., Odagiri, T., Arikawa, J., et al. (1979). Anti-nucleoprotein antibody response in influenza A infection. Tohoku J. Exp. Med. 128, 241-249. doi: 10.1620/tjem.128.241

Sun, J. C., Williams, M. A., and Bevan, M. J. (2004). CD4+ T cells are required for the maintenance, not programming, of memory CD8 $+\mathrm{T}$ cells after acute infection. Nat. Immunol. 5, 927-933. doi: 10.1038/ni1105

Taylor, P. M., and Askonas, B. A. (1986). Influenza nucleoprotein-specific cytotoxic T-cell clones are protective in vivo. Immunology 58, 417-420.

Topham, D. J., and Doherty, P. C. (1998). Clearance of an influenza A virus by CD4+ T cells is inefficient in the absence of B cells. J. Virol. 72, 882-885.

Topham, D. J., Tripp, R. A., and Doherty, P. C. (1997). CD8+ T cells clear influenza virus by perforin or Fas-dependent processes. J. Immunol. 159, 5197-5200.

Topham, D. J., Tripp, R. A., Sarawar, S. R., Sangster, M. Y., and Doherty, P. C. (1996). Immune CD4+ T cells promote the clearance of influenza virus from major histocompatibility complex class II -/- respiratory epithelium. J. Virol. 70, 1288-1291.

Tu, W., Mao, H., Zheng, J., Liu, Y., Chiu, S. S., Qin, G., et al. (2010). Cytotoxic $\mathrm{T}$ lymphocytes established by seasonal human influenza cross-react against 2009 pandemic H1N1 influenza virus. J. Virol. 84, 6527-6535. doi: 10.1128/JVI.00519-10 
Tu, W., Zheng, J., Liu, Y., Sia, S. F., Liu, M., Qin, G., et al. (2011). The aminobisphosphonate pamidronate controls influenza pathogenesis by expanding a gammadelta T cell population in humanized mice. J. Exp. Med. 208, 1511-1522. doi: $10.1084 /$ jem.20110226

Ulmer, J. B., Donnelly, J. J., Parker, S. E., Rhodes, G. H., Felgner, P. L., Dwarki, V. J., et al. (1993). Heterologous protection against influenza by injection of DNA encoding a viral protein. Science 259, 1745-1749. doi: 10.1126/science.8456302

Ulmer, J. B., Fu, T. M., Deck, R. R., Friedman, A., Guan, L., Dewitt, C., et al. (1998). Protective CD4+ and CD8+ T cells against influenza virus induced by vaccination with nucleoprotein DNA. J. Virol. 72, 5648-5653.

Valkenburg, S. A., Quinones-Parra, S., Gras, S., Komadina, N., McVernon, J., Wang, Z., et al. (2013). Acute emergence and reversion of influenza A virus quasispecies within $\mathrm{CD} 8(+) \mathrm{T}$ cell antigenic peptides. Nat. Commun. 4:2663. doi: $10.1038 /$ ncomms 3663

Valkenburg, S. A., Venturi, V., Dang, T. H., Bird, N. L., Doherty, P. C., Turner, S. J., et al. (2012). Early priming minimizes the age-related immune compromise of CD8 T cell diversity and function. PLoS Pathog. 8:e1002544. doi: 10.1371/annotation/e142f9de-7f30-4759-bdal-a651e86d5ba6

Van De Sandt, C. E., Kreijtz, J. H., De Mutsert, G., Geelhoed-Mieras, M. M., Hillaire, M. L., Vogelzang-Van Trierum, S. E., et al. (2014). Human cytotoxic T lymphocytes directed to seasonal influenza A viruses cross-react with the newly emerging H7N9 virus. J. Virol. 88, 1684-1693. doi: 10.1128/JVI.02843-13

Vantourout, P., and Hayday, A. (2013). Six-of-the-best: unique contributions of gammadelta $\mathrm{T}$ cells to immunology. Nat. Rev. Immunol. 13, 88-100. doi: $10.1038 /$ nri3384

Virelizier, J. L., Allison, A. C., Oxford, J. S., and Schild, G. C. (1977). Early presence of ribonucleoprotein antigen on surface of influenza virus-infected cells. Nature 266, 52-54. doi: 10.1038/266052a0

Voeten, J. T., Bestebroer, T. M., Nieuwkoop, N. J., Fouchier, R. A., Osterhaus, A. D., and Rimmelzwaan, G. F. (2000). Antigenic drift in the influenza A virus (H3N2) nucleoprotein and escape from recognition by cytotoxic T lymphocytes. J. Virol. 74, 6800-6807. doi: 10.1128/JVI.74.15.6800-6807.2000

Wahl, A., Schafer, F., Bardet, W., Buchli, R., Air, G. M., and Hildebrand, W. H. (2009). HLA class I molecules consistently present internal influenza epitopes. Proc. Natl. Acad. Sci. U.S.A. 106, 540-545. doi: 10.1073/pnas.0811271106

Wang, T. T., Tan, G. S., Hai, R., Pica, N., Ngai, L., Ekiert, D. C., et al. (2010). Vaccination with a synthetic peptide from the influenza virus hemagglutinin provides protection against distinct viral subtypes. Proc. Natl. Acad. Sci. U.S.A. 107, 18979-18984. doi: 10.1073/pnas.1013387107

Wei, C. J., Boyington, J. C., McTamney, P. M., Kong, W. P., Pearce, M. B., Xu, L., et al. (2010). Induction of broadly neutralizing H1N1 influenza antibodies by vaccination. Science 329, 1060-1064. doi: 10.1126/science.1192517

Whittle, J. R., Zhang, R., Khurana, S., King, L. R., Manischewitz, J., Golding, H., et al. (2011). Broadly neutralizing human antibody that recognizes the receptorbinding pocket of influenza virus hemagglutinin. Proc. Natl. Acad. Sci. U.S.A. 108, 14216-14221. doi: 10.1073/pnas.1111497108
Wilkinson, T. M., Li, C. K., Chui, C. S., Huang, A. K., Perkins, M., Liebner, J. C., et al. (2012). Preexisting influenza-specific CD4+ T cells correlate with disease protection against influenza challenge in humans. Nat. Med. 18, 274-280. doi: $10.1038 / \mathrm{nm} .2612$

Wu, C., Zanker, D., Valkenburg, S., Tan, B., Kedzierska, K., Zou, Q. M., et al. (2011). Systematic identification of immunodominant CD8+ T-cell responses to influenza A virus in HLA-A2 individuals. Proc. Natl. Acad. Sci. U.S.A. 108, 9178-9183. doi: 10.1073/pnas.1105624108

Wu, J. T., Ma, E. S., Lee, C. K., Chu, D. K., Ho, P. L., Shen, A. L., et al. (2010). The infection attack rate and severity of 2009 pandemic H1N1 influenza in Hong Kong. Clin. Infect. Dis. 51, 1184-1191. doi: 10.1086/656740

Yap, K. L., Ada, G. L., and McKenzie, I. F. (1978). Transfer of specific cytotoxic T lymphocytes protects mice inoculated with influenza virus. Nature 273, 238-239. doi: 10.1038/273238a0

Yewdell, J. W., Bennink, J. R., Smith, G. L., and Moss, B. (1985). Influenza A virus nucleoprotein is a major target antigen for cross-reactive anti-influenza A virus cytotoxic T lymphocytes. Proc. Natl. Acad. Sci. U.S.A. 82, 1785-1789. doi: $10.1073 /$ pnas.82.6.1785

Yewdell, J. W., Frank, E., and Gerhard, W. (1981). Expression of influenza A virus internal antigens on the surface of infected P815 cells. J. Immunol. 126, 1814-1819.

Yoshida, R., Igarashi, M., Ozaki, H., Kishida, N., Tomabechi, D., Kida, H., et al. (2009). Cross-protective potential of a novel monoclonal antibody directed against antigenic site B of the hemagglutinin of influenza A viruses. PLoS Pathog. 5:e1000350. doi: 10.1371/journal.ppat. 1000350

Zhao, Y., Zhang, Y. H., Denney, L., Young, D., Powell, T. J., Peng, Y. C., et al. (2012). High levels of virus-specific CD4+ T cells predict severe pandemic influenza A virus infection. Am. J. Respir. Crit. Care Med. 186, 1292-1297. doi: 10.1164/rccm.201207-1245OC

Conflict of Interest Statement: The authors declare that the research was conducted in the absence of any commercial or financial relationships that could be construed as a potential conflict of interest.

Received: 31 March 2014; accepted: 23 May 2014; published online: 12 June 2014. Citation: Quiñones-Parra S, Loh L, Brown LE, Kedzierska $K$ and Valkenburg SA (2014) Universal immunity to influenza must outwit immune evasion. Front. Microbiol. 5:285. doi: 10.3389/fmicb.2014.00285

This article was submitted to Microbial Immunology, a section of the journal Frontiers in Microbiology.

Copyright (c) 2014 Quiñones-Parra, Loh, Brown, Kedzierska and Valkenburg. This is an open-access article distributed under the terms of the Creative Commons Attribution License (CC BY). The use, distribution or reproduction in other forums is permitted, provided the original author(s) or licensor are credited and that the original publication in this journal is cited, in accordance with accepted academic practice. No use, distribution or reproduction is permitted which does not comply with these terms. 